\title{
Trichinella spp. in Wild Boars (Sus scrofa), Brown Bears (Ursus arctos), Eurasian Lynxes (Lynx lynx) and Badgers (Meles meles) in Estonia, 2007-2014
}

\author{
Age Kärssin ${ }^{1,2, *(\mathbb{D})}$, Liidia Häkkinen ${ }^{1}$, Annika Vilem ${ }^{1,2} \mathbb{( D}$, Pikka Jokelainen ${ }^{2,3,4}{ }^{(D)}$ and Brian Lassen ${ }^{5}$ \\ 1 Estonian Veterinary and Food Laboratory, 51006 Tartu, Estonia; liidia.hakkinen@vetlab.ee (L.H.); \\ annika.vilem@vetlab.ee (A.V.) \\ 2 Institute of Veterinary Medicine and Animal Sciences, Estonian University of Life Sciences, \\ 51006 Tartu, Estonia; PIJO@ssi.dk \\ 3 Laboratory of Parasitology, Department of Bacteria, Parasites and Fungi, Infectious Disease Preparedness, \\ Statens Serum Institut, 2300 Copenhagen, Denmark \\ 4 Faculty of Veterinary Medicine, University of Helsinki, 00014 Helsinki, Finland \\ 5 Research Group for Global Capacity Building, Division for Global Surveillance, National Food Institute, \\ Technical University of Denmark, 2800 Copenhagen, Denmark; brlas@food.dtu.dk \\ * Correspondence: age.karssin@vetlab.ee; Tel.: +372-7386-116
}

check for updates

Citation: Kärssin, A.; Häkkinen, L.; Vilem, A.; Jokelainen, P.; Lassen, B. Trichinella spp. in Wild Boars (Sus scrofa), Brown Bears (Ursus arctos), Eurasian Lynxes (Lynx lynx) and Badgers (Meles meles) in Estonia, 2007-2014. Animals 2021, 11, 183. https://doi.org/10.3390/ani110 10183

Received: 7 December 2020 Accepted: 11 January 2021 Published: 14 January 2021

Publisher's Note: MDPI stays neutral with regard to jurisdictional clai$\mathrm{ms}$ in published maps and institutional affiliations.

Copyright: (C) 2021 by the authors. Licensee MDPI, Basel, Switzerland. This article is an open access article distributed under the terms and conditions of the Creative Commons Attribution (CC BY) license (https:// creativecommons.org/licenses/by/ $4.0 /)$.
Simple Summary: Trichinellosis is an important foodborne zoonosis. In Estonia, Trichinella infections are endemic in wild animals. This paper summarizes findings of Trichinella-parasites during an 8-year period in Estonia in selected host species: wild boars, brown bears, Eurasian lynxes, and badgers. The results highlight that testing wildlife hunted for human consumption for Trichinella is important, and that there is room for improvement in the proportion of hunted animals tested.

Abstract: In this study, we summarize Trichinella findings from four wild, free-ranging host species from Estonia during 2007-2014. Trichinella spp. larvae were detected in 281 (0.9\%, 95\% confidence interval (CI) $0.8-1.0$ ) of 30,566 wild boars (Sus scrofa), 63 (14.7\%, 95\% CI 11.6-18.3) of 429 brown bears (Ursus arctos), 59 (65.56\%, 95\% CI 55.3-74.8) of 90 Eurasian lynxes (Lynx lynx), and three (60.0\%, 95\% CI 18.2-92.7) of five badgers (Meles meles). All four European Trichinella species were detected: T. britovi in $0.7 \%$ of the wild boars, $7.2 \%$ of the brown bears, $45.6 \%$ of the lynxes, and $40.0 \%$ of the badgers; T. nativa in $0.1 \%$ of the wild boars, $5.8 \%$ of the brown bears, and $20.0 \%$ of the lynxes; T. pseudospiralis in $0.02 \%$ the wild boars; and T. spiralis in $0.03 \%$ of the wild boars and $4.4 \%$ of the lynxes. The results include the first description from Estonia of T. britovi in brown bear and badgers, T. pseudospiralis in wild boars, and T. spiralis in wild boars and lynxes. The results indicate high infection pressure in the sylvatic cycles across the years-illustrating continuous risk of spillover to domestic cycles and of transmission to humans.

Keywords: foodborne; game meat; Trichinella; wildlife; zoonosis

\section{Introduction}

Trichinella spp. are zoonotic parasitic nematodes that can be transmitted to humans by consumption of undercooked or raw meat of infected animals. A multicriteria-based approach placed Trichinella spiralis as the third and Trichinella spp. other than T. spiralis as the fifth on a prioritization ranking list of foodborne parasites in Europe, and the fourth and the third, respectively, in Eastern Europe [1].

Meat of game animals, especially meat of wild boars (Sus scrofa), is considered one of the main sources of Trichinella infections for humans in Europe [2], and it is acknowledged as the main source in Estonia [3]. Cases of human trichinellosis have been reported from Estonia [4], and the proportion testing positive for antibodies against Trichinella spp. was $3.1 \%$ in the general adult human population and $4.9 \%$ among hunters [5]. 
Trichinella spp. are endemic in wildlife in Estonia [6]. A high proportion, 42.1\%, of investigated wild boars that were hunted in 2012-2013 tested positive for antibodies against Trichinella [7], and the biomass of Trichinella has increased in the main reservoir hosts raccoon dogs (Nyctereutes procyonoides) and red foxes (Vulpes vulpes) [6,8]. To add to the knowledge on epidemiology of these zoonotic parasites, the aim of this study was to summarize Trichinella findings during 2007-2014 in selected sylvatic hosts that are hunted in Estonia: wild boars, brown bears (Ursus arctos), Eurasian lynxes (Lynx lynx), and badgers (Meles meles).

\section{Materials and Methods}

\subsection{Ethics}

No animals were killed for the purpose of this study. No data of the hunters were handled in this study.

\subsection{Setting}

Estonia is a Baltic country located in northeastern Europe. Altogether 158,670 wild boars, 348 brown bears, 797 lynxes and 1527 badgers were hunted in Estonia in 20072014 [9]. Meat of all these host species included in this study is eaten in the country.

\subsection{Samples and Data}

The muscle samples included in this study were collected from wild boars, brown bears, lynxes, and badgers, primarily from the predilection muscle groups (diaphragm, muscles of foreleg, or tongue), from across Estonia in 2007-2014 by hunters and by meat inspectors in game meat processing plants. The samples were sent to the Estonian Veterinary and Food Laboratory for Trichinella testing as part of meat inspection, either for primary or confirmatory testing.

Data on sex and age category of the animal, the county where the animal was hunted, and the year when the animal was hunted were extracted from the submission forms that accompanied the samples. The age category of wild boars, brown bears and lynxes was 'juvenile' for animals the hunters estimated to be up to 2 years of age and 'adult' for animals the hunters estimated to be over two years of age. The counties were categorized into eastern vs. western counties and southern vs. northern counties (Table 1). 


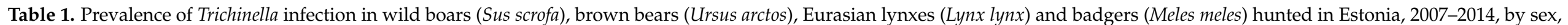

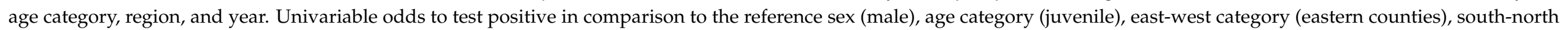
category (southern counties), and year (2007) are shown for each variable, and larval burden data and the Trichinella species identified are summarized.

\begin{tabular}{|c|c|c|c|c|c|c|c|c|c|}
\hline Variable & $\mathbf{N}$ Tested ${ }^{a}$ & $\begin{array}{c}\mathrm{n} \operatorname{pos}^{\mathrm{a}} \\
\left(\mathrm{n} \operatorname{pos}^{\mathrm{a}}, \mathrm{b}\right)\end{array}$ & $\begin{array}{l}\text { Prevalence } \\
(95 \% \mathrm{CI})^{\mathrm{a}}\end{array}$ & $\begin{array}{l}\text { Odds Ratio } \\
(95 \% \mathrm{CI})^{a}\end{array}$ & $p$-Value ${ }^{a}$ & $\begin{array}{c}\text { Median } \\
\operatorname{lpg}^{a, b}\end{array}$ & $\begin{array}{l}\text { Mean } \\
\operatorname{lpg}^{a, b}\end{array}$ & $\begin{array}{l}\text { Range } \\
\operatorname{lpg}^{a, b}\end{array}$ & $\begin{array}{l}\text { Trichinella Species Identified } \\
\text { (n Animals) }{ }^{a, b}\end{array}$ \\
\hline \multicolumn{10}{|c|}{ Wild boars } \\
\hline Sex & & & & & & & & & \\
\hline Male & 2631 & $65(66)$ & $2.5(1.9-3.1)$ & reference & - & 1.43 & 11.89 & $0.02-101.08$ & $\begin{array}{c}\operatorname{Tb}(52), \operatorname{Tn}(6), \operatorname{Tp}(1), \operatorname{Tb}+\operatorname{Tn}(2), \operatorname{Tb}+\operatorname{Ts}(1) \\
\operatorname{Tspp}(4)\end{array}$ \\
\hline Female & 1386 & $45(47)$ & $3.2(2.4-4.3)$ & $1.3(0.9-1.9)$ & 0.157 & 0.58 & 10.59 & $0.02-100.00$ & $\operatorname{Tb}(40), \operatorname{Tn}(2), \operatorname{Tb}+\operatorname{Ts}(1), \operatorname{Tspp}(4)$ \\
\hline Unknown & 26,549 & $171(183)$ & $0.6(0.6-0.7)$ & & & $2.12^{c}$ & $16.30^{\mathrm{c}}$ & $0.01-654.50^{c}$ & $\begin{array}{c}\mathrm{Tb}(123), \operatorname{Tn}(7), \operatorname{Ts}(5), \operatorname{Tp}(5), \operatorname{Tb}+\operatorname{Tn}(3) \\
\operatorname{Tb}+\mathrm{Ts}(1), \operatorname{Tspp}(39)\end{array}$ \\
\hline \multicolumn{10}{|r|}{ (10) } \\
\hline Juvenile & 3992 & $67(68)$ & $1.7(1.3-2.1)$ & reference & - & 0.82 & 12.56 & $0.02-100.00$ & $\mathrm{~Tb}(54), \operatorname{Tn}(5), \mathrm{Tb}+\mathrm{Ts}(1), \operatorname{Tspp}(8)$ \\
\hline Adult & 2057 & $60(62)$ & $2.9(2.3-3.7)$ & $1.7(1.2-2.4)$ & $0.003^{* *}$ & 1.57 & 9.87 & $0.02-101.08$ & $\operatorname{Tb}(53), \operatorname{Tn}(2), \operatorname{Tb}+\operatorname{Tn}(2), \operatorname{Tb}+\operatorname{Ts}(1), \operatorname{Tspp}(4)$ \\
\hline Unknown & 24,517 & $154(166)$ & $0.6(0.5-0.7)$ & & & $2.18^{c}$ & $16.86^{\mathrm{c}}$ & $0.01-654.50^{c}$ & $\begin{array}{c}\mathrm{Tb}(108), \operatorname{Tn}(8), \operatorname{Ts}(5), \operatorname{Tp}(6), \mathrm{Tb}+\operatorname{Tn}(3) \\
\mathrm{Tb}+\mathrm{Ts}(1), \operatorname{Tspp}(35)\end{array}$ \\
\hline $\begin{array}{c}\text { Region } \\
\text { Eastern counties }\end{array}$ & 8449 & $76(79)$ & $0.9(0.7-1.1)$ & reference & - & 0.83 & 11.17 & $0.02-230.88$ & $\operatorname{Tb}(47), \operatorname{Tn}(10), \operatorname{Ts}(1), \operatorname{Tb}+\operatorname{Tn}(2), \operatorname{Tspp}(19)$ \\
\hline Western counties & 10,054 & $196(208)$ & $1.95(1.7-2.2)$ & $2.2(1.7-2.9)$ & $<0.001 * * *$ & 2.44 & 15.99 & $0.01-654.50$ & $\begin{array}{c}\mathrm{Tb}(162), \operatorname{Tn}(5), \mathrm{Tp}(6), \mathrm{Ts}(4) \mathrm{Tb}+\mathrm{Tn}(3) \\
\mathrm{Tb}+\mathrm{Ts}(3), \operatorname{Tspp}(25)\end{array}$ \\
\hline Southern counties & 8204 & $103(115)$ & $1.3(1.0-1.5)$ & reference & - & 2.58 & 12.95 & $0.01-190.00$ & $\operatorname{Tb}(75), \operatorname{Tn}(7), \operatorname{Tp}(6), \operatorname{Ts}(3), \operatorname{Tb}+\operatorname{Tn}(4), \operatorname{Tspp}$ \\
\hline Northern counties & 10,299 & $169(172)$ & $1.6(1.4-1.9)$ & $1.3(1.0-1.7)$ & $0.026^{*}$ & 1.43 & 15.89 & $0.02-654.50$ & $\begin{array}{c}\mathrm{Tb}(134), \operatorname{Tn}(8), \mathrm{Ts}(2), \mathrm{Tb}+\mathrm{Tn}(1), \mathrm{Tb}+\mathrm{Ts}(3), \\
\mathrm{Tspp}(24)\end{array}$ \\
\hline $\begin{array}{l}\text { Unknown } \\
\text { Year }\end{array}$ & 12,063 & $9(9)$ & $0.1(0.04-0.1)$ & & & $1.73^{c}$ & $3.25^{c}$ & $0.06-12.54^{\mathrm{c}}$ & $\operatorname{Tb}(6), \operatorname{Tspp}(3)$ \\
\hline 2007 & 2422 & $10(12)$ & $0.4(0.2-0.7)$ & reference & - & 2.55 & 26.15 & $0.10-100.00$ & $\mathrm{~Tb}(4), \operatorname{Tspp}(8)$ \\
\hline 2008 & 2758 & $10(13)$ & $0.4(0.2-0.6)$ & $0.9(0.4-2.2)$ & 0.774 & $6.00^{c}$ & $13.01^{\mathrm{c}}$ & $0.42-58.00^{c}$ & $\mathrm{~Tb}(3), \operatorname{Tspp}(10)$ \\
\hline 2009 & 4380 & $30(37)$ & $0.7(0.5-1.0)$ & $1.7(0.8-3.6)$ & 0.160 & 2.40 & 8.92 & $0.01-52.15$ & $\mathrm{~Tb}(20), \mathrm{Tp}(2), \mathrm{Ts}(5), \mathrm{Tb}+\mathrm{Ts}(1), \mathrm{Tspp}(9)$ \\
\hline 2010 & 3598 & $26(27)$ & $0.7(0.5-1.0)$ & $1.8(0.9-3.8)$ & 0.127 & 2.68 & 13.72 & $0.02-100.00$ & $\operatorname{Tb}(22), \operatorname{Tn}(1), \operatorname{Tb}+\operatorname{Tn}(1), \operatorname{Tspp}(3)$ \\
\hline 2011 & 2713 & $33(35)$ & $1.2(0.9-1.7)$ & $3.0(1.5-6.3)$ & $0.001^{* * *}$ & 3.44 & 17.88 & $0.02-230.88$ & $\mathrm{~Tb}(25), \operatorname{Tn}(3), \mathrm{Tb}+\operatorname{Tn}(2), \operatorname{Tspp}(5)$ \\
\hline 2012 & 3986 & $26(26)$ & $0.7(0.4-0.9)$ & $1.6(0.8-3.4)$ & 0.217 & 0.89 & 31.40 & $0.02-654.50$ & $\operatorname{Tb}(20), \operatorname{Tn}(1), \operatorname{Tp}(2), \operatorname{Tspp}(3)$ \\
\hline 2013 & 4715 & $77(77)$ & $1.6(1.3-2.0)$ & $4.0(2.1-8.2)$ & $<0.001^{* * *}$ & 1.60 & 9.07 & $0.02-60.00$ & $\mathrm{~Tb}(66), \operatorname{Tn}(4), \operatorname{Tp}(1), \mathrm{Tb}+\operatorname{Tn}(2), \operatorname{Tspp}(4)$ \\
\hline 2014 & 5994 & $69(69)$ & $1.2(0.9-1.4)$ & $2.8(1.5-5.8)$ & $<0.001 * * *$ & 0.82 & 13.59 & $0.02-191.36$ & $\mathrm{~Tb}(55), \operatorname{Tn}(6), \mathrm{Tp}(1), \mathrm{Tb}+\mathrm{Ts}(2), \mathrm{Tspp}(5)$ \\
\hline Wild boars total & 30,566 & $281(296)$ & $0.9(0.8-1.0)$ & & & $1.64^{\mathrm{c}}$ & $14.40^{c}$ & $0.01-654.50^{c}$ & $\begin{array}{c}\mathrm{Tb}(215), \operatorname{Tn}(15), \operatorname{Tp}(6), \mathrm{Ts}(5), \mathrm{Tb}+\mathrm{Tn}(5) \\
\operatorname{Tb}+\mathrm{Ts}(3), \operatorname{Tspp}(47)\end{array}$ \\
\hline
\end{tabular}


Table 1. Cont.

\begin{tabular}{|c|c|c|c|c|c|c|c|c|c|}
\hline Variable & N Tested ${ }^{a}$ & $\begin{array}{c}n \operatorname{pos}^{a} \\
\left(n \operatorname{pos}^{a, b}\right)\end{array}$ & $\begin{array}{l}\text { Prevalence } \\
(95 \% \text { CI })^{\text {a }}\end{array}$ & $\begin{array}{l}\text { Odds Ratio } \\
(95 \% \text { CI })^{a}\end{array}$ & $p$-Value ${ }^{\text {a }}$ & $\begin{array}{c}\text { Median } \\
\operatorname{lpg}^{a, b}\end{array}$ & $\begin{array}{l}\text { Mean } \\
\operatorname{lpg}^{a, b}\end{array}$ & $\begin{array}{l}\text { Range } \\
\operatorname{lpg}^{a, b}\end{array}$ & $\begin{array}{c}\text { Trichinella Species Identified } \\
\text { (n Animals) }{ }^{\mathrm{a}, \mathrm{b}}\end{array}$ \\
\hline \multicolumn{10}{|c|}{ Brown bears } \\
\hline \multicolumn{10}{|l|}{ Sex } \\
\hline Male & 26 & $13(13)$ & $\begin{array}{c}50.0 \\
(31.3-68.7)\end{array}$ & reference & - & 0.20 & 1.17 & $0.02-10.96$ & $\operatorname{Tb}(7), \operatorname{Tn}(1), \operatorname{Tspp}(5)$ \\
\hline Female & 14 & $9(9)$ & $\begin{array}{c}64.3 \\
(37.6-85.6)\end{array}$ & $1.8(0.5-7.3)$ & 0.413 & 3.48 & 4.81 & $0.02-11.02$ & $\operatorname{Tb}(4), \operatorname{Tn}(4), \operatorname{Tb}+\operatorname{Tn}(1)$ \\
\hline \multicolumn{10}{|l|}{ Age category } \\
\hline Juvenile & 22 & $2(2)$ & $9.1(1.55-26.9)$ & reference & - & 4.53 & 4.53 & $0.70-8.36$ & $\operatorname{Tb}(1), \operatorname{Tn}(1)$ \\
\hline Adult & 87 & $19(19)$ & $\begin{array}{c}21.8 \\
(14.1-31.4)\end{array}$ & $2.8(0.7-19.0)$ & 0.185 & 0.86 & 3.00 & $0.02-11.02$ & $\operatorname{Tb}(10), \operatorname{Tn}(5), \operatorname{Tb}+\operatorname{Tn}(2), \operatorname{Tspp}(2)$ \\
\hline Unknown & 320 & $42(43)$ & $\begin{array}{c}13.1 \\
(9.75-17.2)\end{array}$ & & & 0.24 & 4.50 & $0.02-81.96$ & $\operatorname{Tb}(18), \operatorname{Tn}(16), \operatorname{Tb}+\operatorname{Tn}(1), \operatorname{Tspp}(8)$ \\
\hline \multicolumn{10}{|l|}{ Region } \\
\hline Eastern counties & 304 & $48(48)$ & $\begin{array}{c}15.8 \\
(12.0-20.2)\end{array}$ & reference & - & 0.42 & 4.78 & $0.03-81.96$ & $\operatorname{Tb}(20), \operatorname{Tn}(18), \operatorname{Tspp}(10)$ \\
\hline Western counties & 72 & $12(13)$ & $16.7(9.4-26.6)$ & $1.1(0.5-2.1)$ & 0.839 & 0.13 & 2.06 & $0.02-10.76$ & $\operatorname{Tb}(7), \operatorname{Tn}(3), \operatorname{Tb}+\operatorname{Tn}(3)$ \\
\hline Northern counties & 235 & $44(44)$ & $\begin{array}{c}18.7 \\
(14.1-24.1)\end{array}$ & $1.8(1.0-3.4)$ & 0.058 & 0.77 & 3.40 & $0.02-29.96$ & $\operatorname{Tb}(17), \operatorname{Tn}(17), \operatorname{Tb}+\operatorname{Tn}(2), \operatorname{Tspp}(2)$ \\
\hline $\begin{array}{l}\text { Unknown } \\
\text { Year }\end{array}$ & 53 & $3(3)$ & $5.7(1.5-14.6)$ & & & 0.76 & 1.11 & $0.20-2.36$ & $\operatorname{Tb}(2), \operatorname{Tn}(1)$ \\
\hline 2007 & 46 & $8(8)$ & $17.4(8.4-30.4)$ & reference & - & 0.35 & 0.95 & $0.03-4.10$ & $\operatorname{Tb}(2), \operatorname{Tn}(1), \operatorname{Tspp}(5)$ \\
\hline 2008 & 50 & $5(5)$ & $10.0(3.8-20.8)$ & $0.5(0.1-1.8)$ & 0.311 & 0.60 & 1.01 & $0.06-2.03$ & $\mathrm{~Tb}(3), \operatorname{Tspp}(2)$ \\
\hline 2009 & 51 & $7(8)$ & $13.7(6.2-25.3)$ & $0.8(0.2-2.3)$ & 0.631 & 0.44 & 4.71 & $0.06-15.90$ & $\mathrm{~Tb}(3), \operatorname{Tn}(3), \operatorname{Tspp}(2)$ \\
\hline 2010 & 64 & $9(9)$ & $14.1(7.1-24.2)$ & $0.8(0.3-2.3)$ & 0.641 & 0.20 & 1.53 & $0.02-9.48$ & $\operatorname{Tb}(7), \operatorname{Tn}(2)$ \\
\hline 2011 & 64 & $8(8)$ & $12.5(6.0-22.4)$ & $0.7(0.2-2.0)$ & 0.487 & 3.44 & 5.53 & $0.04-16.34$ & $\operatorname{Tb}(5), \operatorname{Tn}(3)$ \\
\hline 2012 & 74 & $8(8)$ & $12.2(6.1-21.1)$ & $0.6(0.2-1.7)$ & 0.320 & 0.85 & 4.61 & $0.02-28.96$ & $\operatorname{Tb}(1), \operatorname{Tn}(5), \operatorname{Tb}+\operatorname{Tn}(2)$ \\
\hline 2013 & 42 & $15(15)$ & $\begin{array}{c}35.7 \\
(22.4-51.0)\end{array}$ & $2.6(1.0-7.4)$ & 0.057 & 0.19 & 2.43 & $0.06-11.02$ & $\operatorname{Tb}(7), \operatorname{Tn}(6), \operatorname{Tb}+\operatorname{Tn}(1), \operatorname{Tspp}(1)$ \\
\hline 2014 & 38 & $3(3)$ & $7.9(2.1-20.0)$ & $0.4(0.1-1.6)$ & 0.220 & 0.10 & 27.39 & $0.10-81.96$ & $\operatorname{Tb}(1), \operatorname{Tn}(2)$ \\
\hline Brown bears total & 429 & $63(64)$ & $\begin{array}{c}14.7 \\
(11.6-18.3)\end{array}$ & & & 0.44 & 4.11 & $0.02-81.96$ & $\mathrm{~Tb}(29), \operatorname{Tn}(22), \mathrm{Tb}+\mathrm{Tn}(3), \operatorname{Tspp}(10)$ \\
\hline
\end{tabular}


Table 1. Cont.

\begin{tabular}{|c|c|c|c|c|c|c|c|c|c|}
\hline Variable & N Tested ${ }^{a}$ & $\begin{array}{c}n \operatorname{pos}^{a} \\
\left(n \operatorname{pos}^{a, b}\right)\end{array}$ & $\begin{array}{l}\text { Prevalence } \\
(95 \% \mathrm{CI})^{\mathrm{a}}\end{array}$ & $\begin{array}{l}\text { Odds Ratio } \\
(95 \% \mathrm{CI})^{\mathrm{a}}\end{array}$ & $p$-Value ${ }^{\text {a }}$ & $\begin{array}{l}\text { Median } \\
\operatorname{lpg}^{a, b}\end{array}$ & $\begin{array}{l}\text { Mean } \\
\operatorname{lpg}^{a, b}\end{array}$ & $\begin{array}{l}\text { Range } \\
\text { lpg }{ }^{a, b}\end{array}$ & $\begin{array}{l}\text { Trichinella Species Identified } \\
\text { (n Animals) }{ }^{a, b}\end{array}$ \\
\hline \multicolumn{10}{|c|}{ Lynxes } \\
\hline \multicolumn{10}{|l|}{ Sex } \\
\hline Male & 14 & $14(14)$ & $\begin{array}{c}100.0 \\
(80.7-100.0)\end{array}$ & reference & - & 2.38 & 6.51 & $0.20-28.00$ & $\operatorname{Tb}(9), \operatorname{Tn}(1), \operatorname{Tb}+\operatorname{Tn}(4)$ \\
\hline Female & 10 & $8(8)$ & $\begin{array}{c}80.0 \\
(48.1-96.5)\end{array}$ & - & 0.163 & 0.90 & 4.14 & $0.38-20.10$ & $\operatorname{Tb}(3), \operatorname{Tn}(2), \operatorname{Ts}(1), \operatorname{Tb}+\operatorname{Tn}(1), \operatorname{Tspp}(1)$ \\
\hline Unknown & 66 & $37(41)$ & $\begin{array}{c}56.1 \\
(44.0-67.7)\end{array}$ & & & $1.20^{\mathrm{c}}$ & $3.53^{c}$ & $0.02-21.40^{c}$ & $\begin{array}{c}\operatorname{Tb}(15), \operatorname{Tn}(1), \operatorname{Ts}(3), \operatorname{Tb}+\operatorname{Tn}(10), \operatorname{Tb}+\operatorname{Ts}(1) \\
\operatorname{Tspp}(12)\end{array}$ \\
\hline \multicolumn{10}{|l|}{ Age category } \\
\hline Juvenile & 15 & $7(7)$ & $\begin{array}{c}46.7 \\
(23.2-71.3)\end{array}$ & reference & - & 14.88 & 10.97 & $0.20-28.00$ & $\operatorname{Tb}(3), \operatorname{Ts}(1), \operatorname{Tb}+\operatorname{Tn}(3)$ \\
\hline Adult & 17 & $14(14)$ & $\begin{array}{c}82.4 \\
(59.1-95.3)\end{array}$ & $5.0(1.0-30.2)$ & $0.045^{*}$ & 1.91 & 2.78 & $0.04-9.22$ & $\operatorname{Tb}(6), \operatorname{Tn}(2), \operatorname{Ts}(1), \operatorname{Tb}+\operatorname{Tn}(4), \operatorname{Tspp}(1)$ \\
\hline Unknown & 58 & $38(42)$ & $\begin{array}{c}65.5 \\
(52.7-76.9)\end{array}$ & & & $0.99^{c}$ & $3.65^{c}$ & $0.02-21.40^{\mathrm{c}}$ & $\begin{array}{c}\mathrm{Tb}(18), \operatorname{Tn}(2), \operatorname{Ts}(2), \mathrm{Tb}+\mathrm{Tn}(8), \mathrm{Tb}+\mathrm{Ts}(1) \\
\operatorname{Tspp}(1)\end{array}$ \\
\hline \multicolumn{10}{|r|}{ - } \\
\hline Western counties & 27 & $23(25)$ & $\begin{array}{c}85.2 \\
(68.0-95.1)\end{array}$ & $3.8(1.2-14.2)$ & $0.020 *$ & 2.34 & 6.49 & $0.1-28.00$ & $\operatorname{Tb}(11), \operatorname{Tn}(3), \operatorname{Ts}(3), \operatorname{Tb}+\operatorname{Tn}(7), \operatorname{Tspp}(1)$ \\
\hline Southern counties & 33 & $18(21)$ & $\begin{array}{c}54.5 \\
(37.5-70.8)\end{array}$ & reference & - & 2.42 & 3.66 & $0.02-14.60$ & $\operatorname{Tb}(9), \operatorname{Tn}(1), \operatorname{Ts}(2), \operatorname{Tb}+\operatorname{Tn}(9)$ \\
\hline Northern counties & 54 & $41(42)$ & $\begin{array}{c}75.9 \\
(63.2-85.9)\end{array}$ & $2.6(1.0-6.7)$ & $0.045^{*}$ & $1.14^{\mathrm{c}}$ & $4.62^{c}$ & $0.16-28.00^{\mathrm{c}}$ & $\begin{array}{c}\mathrm{Tb}(18), \operatorname{Tn}(3), \operatorname{Ts}(2), \operatorname{Tb}+\operatorname{Tn}(6), \mathrm{Tb}+\mathrm{Ts}(1) \\
\operatorname{Tspp}(12)\end{array}$ \\
\hline $\begin{array}{l}\text { Unknown } \\
\text { Year }\end{array}$ & 3 & $0(0)$ & $0.0(0.0-63.2)$ & & & - & - & - & - \\
\hline 2007 & 10 & $5(6)$ & $\begin{array}{c}50.0 \\
(21.2-78.8)\end{array}$ & reference & - & $1.45^{\mathrm{c}}$ & $6.25^{c}$ & $0.70-21.40^{c}$ & $\mathrm{~Tb}+\operatorname{Tn}(1), \operatorname{Tspp}(5)$ \\
\hline 2008 & 12 & $5(5)$ & $\begin{array}{c}41.7 \\
(17.2-69.8)\end{array}$ & $0.7(0.1-4.2)$ & 0.721 & 0.90 & 2.18 & $0.50-7.60$ & $\mathrm{~Tb}(3), \operatorname{Tspp}(2)$ \\
\hline 2009 & 20 & $14(16)$ & $\begin{array}{c}70.0 \\
(47.7-86.8)\end{array}$ & $2.3(0.5-11.8)$ & 0.321 & 0.50 & 2.08 & $0.10-14.88$ & $\mathrm{~Tb}(5), \mathrm{Ts}(4), \mathrm{Tb}+\mathrm{Tn}(3), \mathrm{Tb}+\mathrm{Ts}(1), \mathrm{Tspp}(3)$ \\
\hline 2010 & 17 & $11(12)$ & $\begin{array}{c}64.7 \\
(40.5-84.3)\end{array}$ & $1.8(0.35-9.5)$ & 0.487 & 0.82 & 2.73 & $0.20-14.60$ & $\operatorname{Tb}(9), \operatorname{Tn}(1), \operatorname{Tb}+\operatorname{Tn}(2)$ \\
\hline
\end{tabular}


Table 1. Cont.

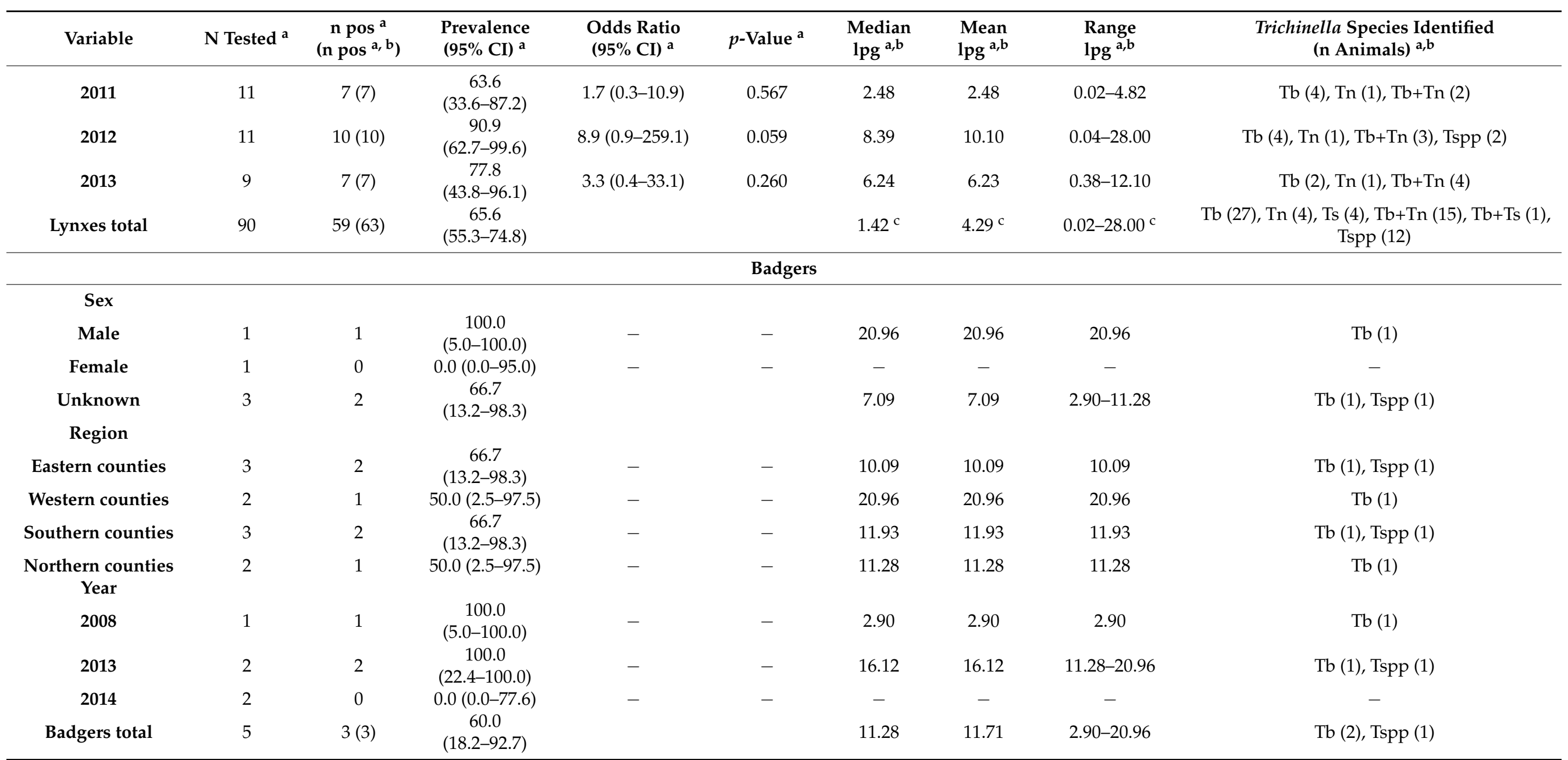

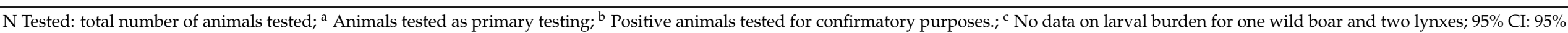

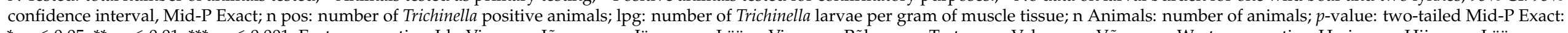

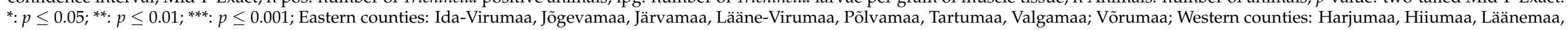

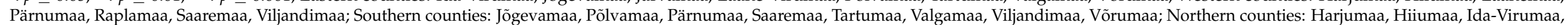

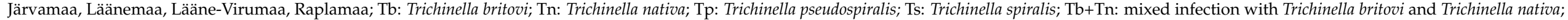
Tb+Ts: mixed infection with Trichinella britovi and Trichinella spiralis; Tspp: Trichinella species, no species-level result. 


\subsection{Artificial Digestion}

The artificial digestion of the samples was carried out at the Estonian Veterinary and Food Laboratory, which is the national reference laboratory for parasites with its three regional laboratories. The laboratories are accredited by ISO 17025 and authorized as official laboratories for Trichinella digestion analyses according to EU 2075/2005 Annex I Chapter 1 [10]. One of the regional laboratories used Stomacher method according to EU 2075/2005 Annex I Chapter II [10] until 2009.

The testing included both primary and confirmatory testing. Other laboratories performing Trichinella testing send positive samples to the national reference laboratory for confirmation and species identification.

A minimum of $10 \mathrm{~g}$ muscle tissue was used from each animal in a pooled sample and $50 \mathrm{~g}$ for an individual sample, with the exception that in 2007, one regional laboratory used $5 \mathrm{~g}$ muscle tissue as the minimum in pooled samples for up to 20 animals. If a pooled sample was positive, the pool was divided into smaller pools and individual samples were tested to identify the infected animals.

If larvae were found, they were identified morphologically, counted, washed with tap water, and stored in ethanol, according to the procedures recommended by the European Union Reference Laboratory for Parasites [11]. The number of larvae per gram of muscle tissue (lpg) was calculated for each positive animal.

\subsection{Molecular Analysis}

Larvae collected in 2007-2010 were identified to the species level at the European Union Reference Laboratory [11], and larvae collected since 2011 at the Estonian Veterinary and Food Laboratory. The same multiplex PCR [12] was used for all the analyses. The method does not include sequencing.

\subsection{Statistical Analyses}

Only results from primary testing were used for prevalence estimates. Animals were excluded from statistical analyses if their individual infection status could not be determined, due to testing as part of a pooled sample followed by unsuccessful identification of the infected individuals.

We compared the prevalence estimates by sex, by age group, by eastern vs western counties and by southern vs northern counties, using two-by-two tables. In addition, we report univariable odds ratios for testing positive for Trichinella, using these same dichotomous variables, as well as counties as dummy variables and years as dummy variables.

For the statistical analyses, we used Microsoft Excel, OpenEpi and R [13,14]. We report $95 \%$ confidence intervals ( $95 \%$ CI, Mid-P Exact) for proportions. Associations were considered statistically significant if two-tailed $p<0.05$.

\section{Results}

The proportion of animals included in this study from the officially reported hunting bag of the study period was $19.3 \%$ for wild boars, $123.6 \%$ for brown bears, $12.0 \%$ for lynxes and $0.3 \%$ for badgers [9]. A total of 44 wild boars and two lynxes were excluded from statistical analyses, because their individual infection status could not be determined. The final sample was 31,090 animals tested as primary testing (Table S1), and 20 positive animals (15 wild boars, one brown bear and four lynxes) that had been tested for confirmatory purposes. Data on larval burden were missing for one wild boar and two lynxes. For Trichinella spp. species identification, altogether 426 larval samples were tested; Trichinella species was not determined in $70(16.4 \%)$ of the larval samples.

Of the altogether 31,090 animals tested as primary testing, 406 (1.3\%, 95\% CI 1.2-1.4) were positive for Trichinella spp. larvae. Altogether $281(0.9 \%$, 95\% CI 0.8-1.0) of the 30,566 wild boars, $63(14.7 \%$, 95\% CI 11.6-18.3) of the 429 brown bears, $59(65.6 \%$, 95\% CI $55.3-74.8)$ of the 90 lynxes, and three $(60.0 \%, 95 \%$ CI 18.2-92.7) of the five badgers were 
Trichinella positive (Table 1). In wild boars and lynxes, a higher prevalence was observed in adults than in juveniles ( $p=0.003$ and $p=0.045$, respectively) (Table 1$)$. In wild boars, the prevalence was higher in the western counties than in the eastern counties $(p<0.001)$, and in the northern counties than in the southern counties $(p=0.026)$ (Table 1). The prevalence in lynxes was higher in the eastern counties than in the western counties $(p=0.020)$, and in the northern counties than in the southern counties $(p=0.045)$. The prevalence varied by year from $0.4 \%$ to $1.6 \%$ in wild boars, from $7.9 \%$ to $36.7 \%$ in brown bears, from $41.7 \%$ to $90.9 \%$ in lynxes, and from $0.0 \%$ to $100.0 \%$ in badgers (Figure 1, Table 1 ). In wild boars, the prevalence was higher in $2011(p=0.001), 2013(p<0.001)$, and $2014(p<0.001)$ than it was in 2007 (Table 1).

The larval burden appeared generally higher in wild boars than in brown bears and lynxes (Figure 1, Table 1). Nine wild boars had more than $100 \mathrm{lpg}$.

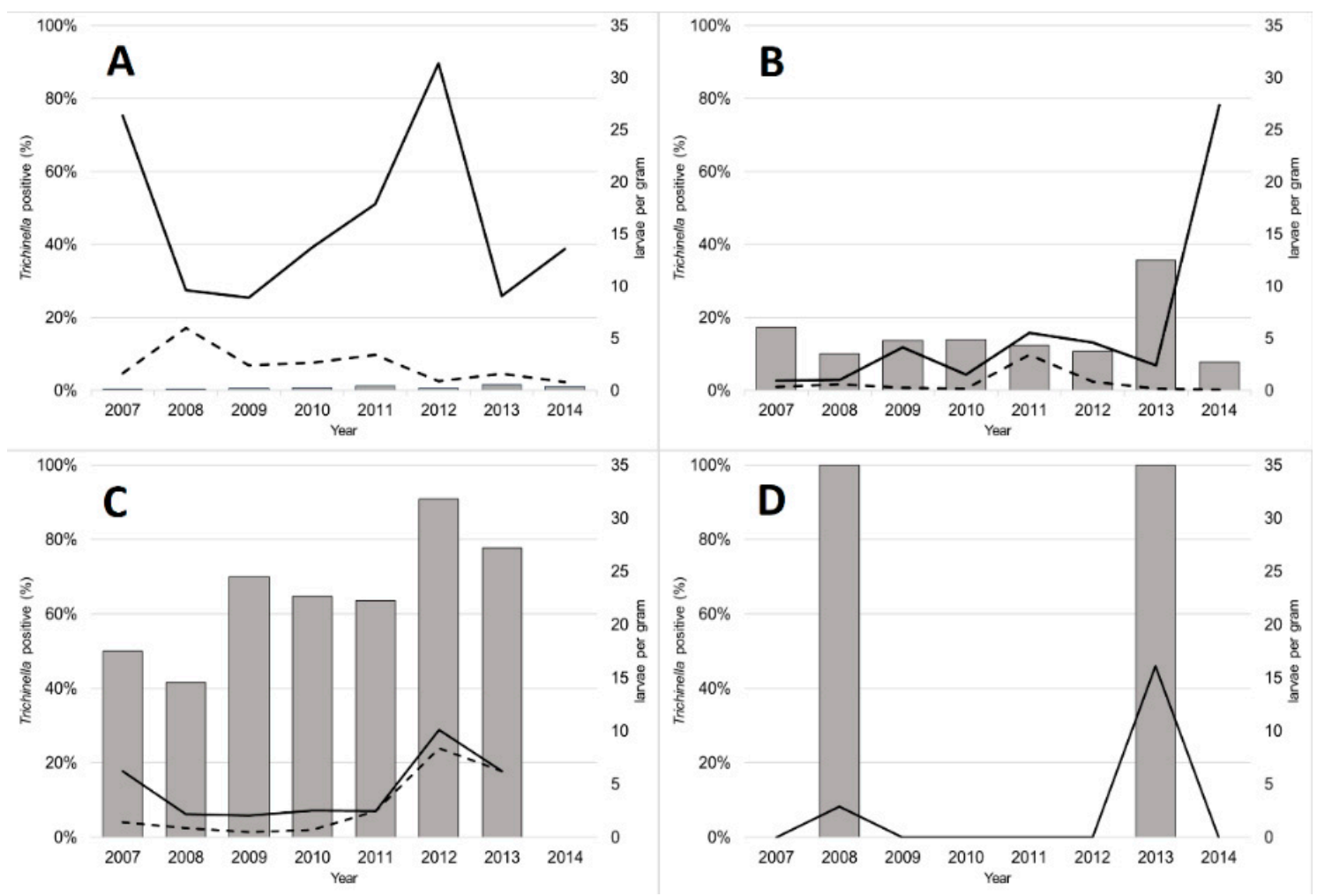

Figure 1. Percentage of Trichinella spp. positive animals; Mean (solid line) and median (dashed line) number of larvae per gram tissue in tested wild boars (Sus scrofa, A), brown bears (Ursus arctos, B), Eurasian lynxes (Lynx lynx, C) and badgers (Meles meles, D), 2007-2014, Estonia.

Mono-species Trichinella infection was found in 97.5\% (95\% CI 95.0-99.0) of the wild boars, $94.3 \%$ (95\% CI 85.4-98.5) of the brown bears, $69.4 \%$ (95\% CI 55.5-81.0) of the lynxes, and all badgers that were positive and had the Trichinella species identified. The Trichinella species that were detected are shown by county and by year in Figure 2, Table 1 and Table S2. The isolates of 2007-2010 were deposited in International Trichinella Reference Centre [11].

Trichinella britovi was the most common Trichinella species found in all the investigated host species. It was found in animals from all counties (Figure 2, Table S2), in $0.7 \%$ (95\% CI 0.6-0.8) of wild boars, $7.2 \%$ (95\% CI 5.1-10.0) of brown bears, $45.6 \%$ (95\% CI 35.5-55.9) of lynxes, and $40.0 \%$ (95\% CI 7.4-81.8) of badgers (Table 2). Trichinella britovi infections were found in 31 brown bears: in five hunted in Ida-Virumaa in 2007, 2010 and 2011; in four hunted in Harjumaa in 2010, 2011, 2012, and 2013; in four hunted in Järvamaa in 2008 and 2013; in four hunted in Jõgevamaa in 2011 and 2013; in two hunted in Läänemaa in 2009 and 2010; in four hunted in Lääne-Virumaa in 2009, 2010 and 2013; in one hunted in Põlvamaa 
in 2012; in two hunted in Pärnumaa in 2008 and 2012; and in three hunted in Tartumaa in 2009, 2013 and 2014; and in two badgers, which had been hunted in Lääne-Virumaa and Viljandimaa in 2013 - these are the first confirmed findings of this parasite species in these host species in Estonia (this study; [15]).

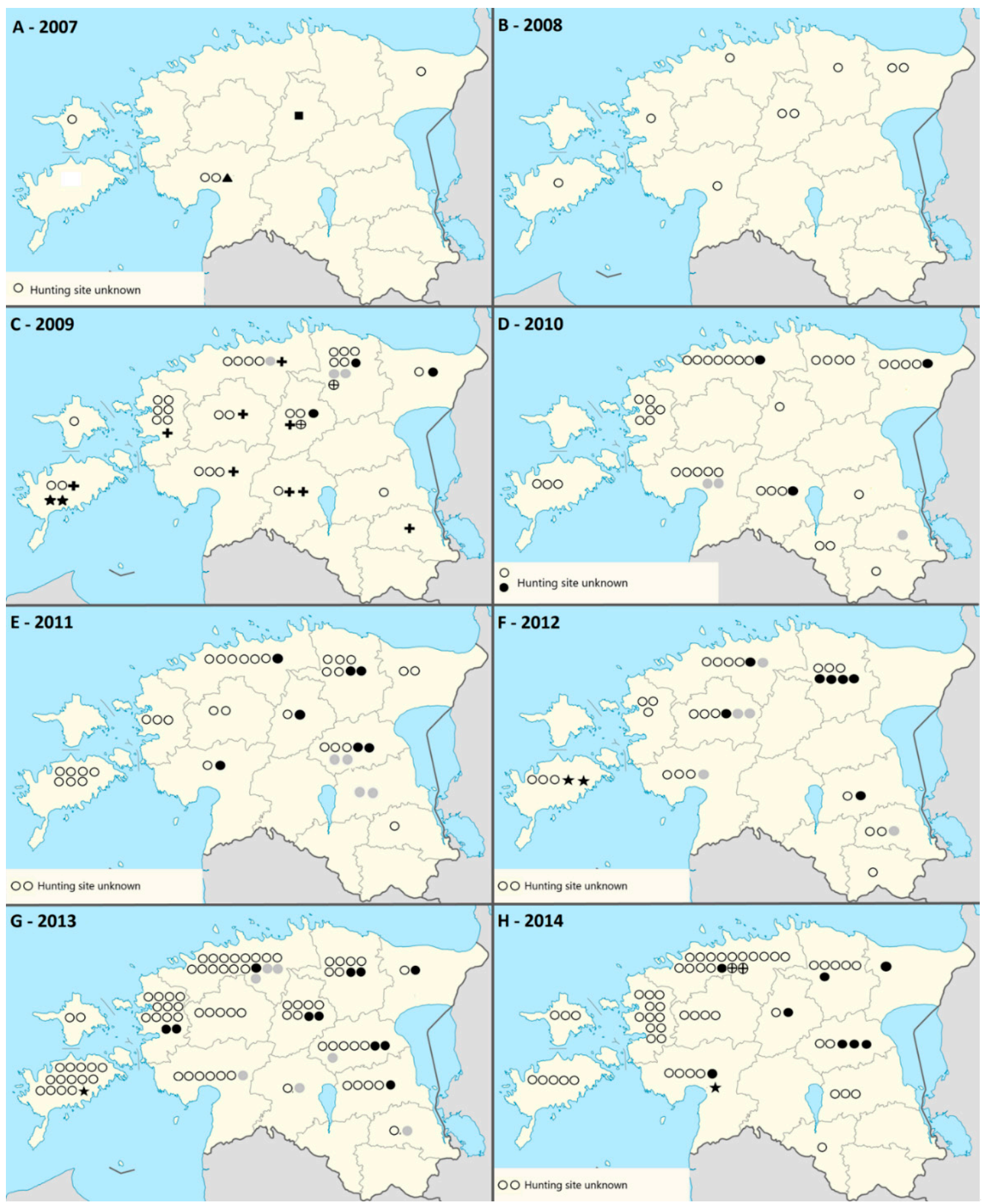

Figure 2. Trichinella species distribution in the tested animals that were positive and Trichinella species identification was successful, 2007-2014 (A-H, respectively), Estonia. T. britovi-ring, T. nativa-black dot, T. pseudospiralis-star; T. spiralis—cross, T. britovi and T. nativa-grey dot, T. britovi and T. spiralis—ring with cross. 
Table 2. Trichinella species identified in wild boars (Sus scrofa), brown bears (Ursus arctos), Eurasian lynxes (Lynx lynx) and badgers (Meles meles) hunted in 2007-2014 in Estonia.

\begin{tabular}{|c|c|c|c|c|c|c|c|c|c|c|c|c|c|c|c|c|}
\hline \multirow[b]{2}{*}{$\begin{array}{l}\text { Trichinella } \\
\text { Species }\end{array}$} & \multicolumn{4}{|c|}{ Wild Boars $\left(n=30,566^{a}+15^{b}\right)$} & \multicolumn{4}{|c|}{ Brown Bears $\left(n=429^{a}+1^{b}\right)$} & \multicolumn{4}{|c|}{ Lynxes $\left(\mathrm{n}=90^{\mathrm{a}}+4^{\mathrm{b}}\right)$} & \multicolumn{4}{|c|}{ Badgers $\left(n=5^{\text {a }}\right)$} \\
\hline & $\underset{\substack{\text { a pos } \\
\text { n pos }}}{a}$ & $\begin{array}{c}\text { Prevalence } \\
\% \\
(95 \% \mathrm{CI})^{\mathrm{a}}\end{array}$ & $\begin{array}{c}\%(95 \% \\
\text { CI) of } \\
\text { Trichinella } \\
\text { Positive } \\
\mathrm{a}, \mathrm{b}\end{array}$ & $\begin{array}{l}\text { Median; } \\
\text { Mean } \\
\text { (Range) of } \\
\text { lpg }^{a, b}\end{array}$ & $\begin{array}{c}\mathrm{n} \text { pos }^{\mathrm{a}} \\
(\mathrm{n} \text { pos } \\
\mathrm{a}, \mathrm{b})\end{array}$ & $\begin{array}{l}\text { Prevalence } \\
\%(95 \% \\
\text { CI })^{\mathrm{a}}\end{array}$ & $\begin{array}{c}\%(95 \% \\
\text { CI) of } \\
\text { Trichinella } \\
\text { Positive } \\
\mathrm{a}, \mathrm{b}\end{array}$ & $\begin{array}{l}\text { Median; } \\
\text { Mean } \\
\text { (Range) of } \\
\text { lpga,b }\end{array}$ & $\begin{array}{c}n \text { pos }^{a} \\
(\mathrm{n} \text { pos } \\
\mathrm{a}, \mathrm{b})\end{array}$ & $\begin{array}{l}\text { Prevalence } \\
\%(95 \% \\
\mathrm{CI})^{\mathrm{a}}\end{array}$ & $\begin{array}{c}\%(95 \% \\
\text { CI) of } \\
\text { Trichinella } \\
\text { Positive } \\
\text { a,b }\end{array}$ & $\begin{array}{l}\text { Median; } \\
\text { Mean } \\
\text { (Range) } \\
\text { of lpg a,b }\end{array}$ & $\begin{array}{l}\text { n pos } \text { po }^{a} \\
(\mathrm{n} \text { pos } \\
\mathrm{a}, \mathrm{b})\end{array}$ & $\begin{array}{c}\begin{array}{c}\text { Prevalence } \\
\% \\
(95 \% \mathrm{CI})^{\mathrm{a}}\end{array}\end{array}$ & $\begin{array}{c}\% \text { (95\% } \\
\text { CI) of } \\
\text { Trichinella } \\
\text { Positive } \\
\mathrm{a}, \mathrm{b}\end{array}$ & $\begin{array}{l}\text { Median; } \\
\text { Mean } \\
\text { (Range) of } \\
\text { lpg }^{\mathrm{a}, \mathrm{b}}\end{array}$ \\
\hline $\begin{array}{l}\text { T. britovi } \\
\text { only }\end{array}$ & $\begin{array}{c}209 \\
(215)\end{array}$ & $\begin{array}{c}0.7 \\
(0.6-0.8)\end{array}$ & $\begin{array}{c}72.6 \\
(67.3-77.5)\end{array}$ & $\begin{array}{c}2.06 ; 16.30 \\
(0.02-654.5)\end{array}$ & $\begin{array}{c}28 \\
(29)\end{array}$ & $\begin{array}{c}6.5 \\
(4.5-9.2)\end{array}$ & $\begin{array}{c}45.3 \\
(33.5-57.6)\end{array}$ & $\begin{array}{c}0.48 ; 5.88 \\
(0.10-81.96)\end{array}$ & $\begin{array}{c}26 \\
(27)\end{array}$ & $\begin{array}{c}28.9 \\
(20.2-38.9)\end{array}$ & $\begin{array}{c}42.9 \\
(31.1-55.3)\end{array}$ & $\begin{array}{c}1.48 ; 4.71 \\
(0.06-28.00)\end{array}$ & $\begin{array}{c}2 \\
(2)\end{array}$ & $\begin{array}{c}40.0 \\
(7.4-81.8)\end{array}$ & $\begin{array}{c}66.7 \\
(13.2-98.3)\end{array}$ & $\begin{array}{c}16.12 ; 16.12 \\
(11.28-20.96)\end{array}$ \\
\hline $\begin{array}{l}\text { T. nativa } \\
\text { only }\end{array}$ & $\begin{array}{l}15 \\
(15)\end{array}$ & $\begin{array}{c}0.05 \\
(0.03-0.08)\end{array}$ & $\begin{array}{c}5.1 \\
(3.0-8.0)\end{array}$ & $\begin{array}{c}0.82 ; 6.69 \\
(0.04-54.32)\end{array}$ & $\begin{array}{c}22 \\
(22)\end{array}$ & $\begin{array}{c}5.1 \\
(3.3-7.5)\end{array}$ & $\begin{array}{c}34.4 \\
(23.5-46.6)\end{array}$ & $\begin{array}{c}0.60 ; 3.40 \\
(0.02-28.96)\end{array}$ & $\begin{array}{l}4 \\
(4)\end{array}$ & $\begin{array}{c}4.4 \\
(1.4-10.4)\end{array}$ & $\begin{array}{c}6.3 \\
(2.1-14.6)\end{array}$ & $\begin{array}{c}3.53 ; 6.80 \\
(0.02-20.10)\end{array}$ & - & - & - & - \\
\hline $\begin{array}{c}\text { T. pseu- } \\
\text { dospiralis } \\
\text { only }\end{array}$ & $\begin{array}{l}6 \\
(6)\end{array}$ & $\begin{array}{c}0.02 \\
(0.01-0.04)\end{array}$ & $\begin{array}{c}2.0 \\
(0.8-4.2)\end{array}$ & $\begin{array}{c}1.63 ; 5.52 \\
(0.18-23.34)\end{array}$ & - & - & - & - & - & - & - & - & - & - & - & - \\
\hline $\begin{array}{l}\text { T. spiralis } \\
\text { only }\end{array}$ & $\begin{array}{c}5 \\
(5)\end{array}$ & $\begin{array}{c}0.02 \\
(0.01-0.04)\end{array}$ & $\begin{array}{c}1.7 \\
(0.6-3.7)\end{array}$ & $\begin{array}{c}4.76 ; 4.51 \\
(0.20-7.65)\end{array}$ & - & - & - & - & $\begin{array}{c}3 \\
(4)\end{array}$ & $\begin{array}{c}3.3 \\
(0.9-8.8)\end{array}$ & $\begin{array}{c}6.3 \\
(2.1-14.6)\end{array}$ & $\begin{array}{c}3.61 ; 5.58 \\
(0.23-14.88)\end{array}$ & - & - & - & - \\
\hline $\begin{array}{l}\text { T. britooi } \\
\text { and } \\
\text { T. nativa }\end{array}$ & $\begin{array}{l}5 \\
(5)\end{array}$ & $\begin{array}{c}0.02 \\
(0.01-0.04)\end{array}$ & $\begin{array}{c}1.7 \\
(0.6-3.7)\end{array}$ & $\begin{array}{c}1.38 ; 10.58 \\
(0.04-45.20)\end{array}$ & $\begin{array}{l}3 \\
(3)\end{array}$ & $\begin{array}{c}0.7 \\
(0.2-1.9)\end{array}$ & $\begin{array}{c}4.7 \\
(1.2-12.2)\end{array}$ & $\begin{array}{c}3.48 ; 2.41 \\
(0.02-3.74)\end{array}$ & $\begin{array}{l}14 \\
(15)\end{array}$ & $\begin{array}{c}15.6 \\
(9.1-24.2)\end{array}$ & $\begin{array}{c}23.8 \\
(14.5-35.5)\end{array}$ & $\begin{array}{c}2.00 ; 4.62 \\
(0.04-17.40)\end{array}$ & - & - & - & - \\
\hline $\begin{array}{l}\text { T. britooi } \\
\text { and } \\
\text { T. spiralis }\end{array}$ & $\begin{array}{c}3 \\
(3)\end{array}$ & $\begin{array}{c}0.01 \\
(0.00-0.03)\end{array}$ & $\begin{array}{c}1.0 \\
(0.3-2.7)\end{array}$ & $\begin{array}{c}0.24 ; 2.67 \\
(0.16-7.60)\end{array}$ & - & - & - & - & $\begin{array}{c}1 \\
(1)\end{array}$ & $\begin{array}{c}1.1 \\
(0.1-5.4)\end{array}$ & $\begin{array}{c}1.6 \\
(0.1-7.6)\end{array}$ & 0.20 & - & - & - & - \\
\hline $\begin{array}{l}\text { T. britovi } \\
\text { Total }^{\mathrm{c}}\end{array}$ & $\begin{array}{c}217 \\
(223)\end{array}$ & $\begin{array}{c}0.7 \\
(0.6-0.8)\end{array}$ & $\begin{array}{c}75.3 \\
(70.2-80.0)\end{array}$ & $\begin{array}{c}1.88 ; 15.99 \\
(0.02-654.50)\end{array}$ & $\begin{array}{c}31 \\
(32)\end{array}$ & $\begin{array}{c}7.2 \\
(5.1-10.0)\end{array}$ & $\begin{array}{c}50.0 \\
(37.9-51.4)\end{array}$ & $\begin{array}{c}0.54 ; 5.56 \\
(0.02-81.96)\end{array}$ & $\begin{array}{c}41 \\
(43)\end{array}$ & $\begin{array}{c}45.6 \\
(35.5-55.9)\end{array}$ & $\begin{array}{c}68.3 \\
(56.0-78.8)\end{array}$ & $\begin{array}{c}1.58 ; 4.23 \\
(0.04-28.00)\end{array}$ & $\begin{array}{c}2 \\
(2)\end{array}$ & $\begin{array}{c}40.0 \\
(7.4-81.8)\end{array}$ & $\begin{array}{c}66.7 \\
(13.2-98.3)\end{array}$ & $\begin{array}{c}16.12 ; 16.12 \\
(11.28-20.96)\end{array}$ \\
\hline $\begin{array}{l}\text { T. nativa } \\
\text { Total }^{\mathrm{c}}\end{array}$ & $\begin{array}{l}20 \\
(20)\end{array}$ & $\begin{array}{c}0.07 \\
(0.04-0.10)\end{array}$ & $\begin{array}{c}6.8 \\
(4.3-10.1)\end{array}$ & $\begin{array}{c}1.14 ; 7.66 \\
(0.04-54.32)\end{array}$ & $\begin{array}{l}25 \\
(25)\end{array}$ & $\begin{array}{c}5.8 \\
(3.9-8.4)\end{array}$ & $\begin{array}{c}39.1 \\
(27.7-51.4)\end{array}$ & $\begin{array}{c}0.76 ; 3.28 \\
(0.02-28.96)\end{array}$ & $\begin{array}{l}18 \\
(19)\end{array}$ & $\begin{array}{c}20.0 \\
(12.7-29.2)\end{array}$ & $\begin{array}{c}30.2 \\
(19.8-42.3)\end{array}$ & $\begin{array}{c}2.00 ; 5.08 \\
(0.02-20.10)\end{array}$ & & - & - & - \\
\hline $\begin{array}{l}\text { T. spiralis } \\
\text { Total }^{\mathrm{c}}\end{array}$ & $\begin{array}{c}8 \\
(8)\end{array}$ & $\begin{array}{c}0.03 \\
(0.01-0.05)\end{array}$ & $\begin{array}{c}2.7 \\
(1.3-5.1)\end{array}$ & $\begin{array}{c}4.26 ; 3.82 \\
(0.16-7.65)\end{array}$ & - & - & - & - & $\begin{array}{l}4 \\
(5)\end{array}$ & $\begin{array}{c}4.4 \\
(1.4-10.4)\end{array}$ & $\begin{array}{c}7.9 \\
(3.0-16.7)\end{array}$ & $\begin{array}{c}3.60 ; 4.51 \\
(0.20-14.88)\end{array}$ & & - & - & - \\
\hline $\begin{array}{l}\text { Species- } \\
\text { level } \\
\text { result total }\end{array}$ & $\begin{array}{c}243 \\
(249)\end{array}$ & $\begin{array}{c}0.8 \\
(0.7-0.9)\end{array}$ & $\begin{array}{c}84.1 \\
(79.6-88.0)\end{array}$ & $\begin{array}{c}1.76 ; 15.07 \\
(0.02-654.50)\end{array}$ & $\begin{array}{l}53 \\
(54)\end{array}$ & $\begin{array}{c}12.4 \\
(9.5-15.7)\end{array}$ & $\begin{array}{c}84.4 \\
(73.9-91.8)\end{array}$ & $\begin{array}{c}0.60 ; 4.76 \\
(0.02-81.96)\end{array}$ & $\begin{array}{l}48 \\
(51)\end{array}$ & $\begin{array}{c}53.3 \\
(43.0-63.5)\end{array}$ & $\begin{array}{c}81.0 \\
(69.9-89.3)\end{array}$ & $\begin{array}{c}1.64 ; 4.54 \\
(0.02-28.00)\end{array}$ & $\begin{array}{l}2 \\
(2)\end{array}$ & $\begin{array}{c}40.0 \\
(7.4-81.8)\end{array}$ & $\begin{array}{c}66.7 \\
(13.2-98.3)\end{array}$ & $\begin{array}{r}16.12 ; 16.12 \\
(11.28-20.96)\end{array}$ \\
\hline $\begin{array}{l}\text { No } \\
\text { species- } \\
\text { level } \\
\text { result }\end{array}$ & $\begin{array}{l}38 \\
(47)\end{array}$ & $\begin{array}{c}0.1 \\
(0.1-0.2)\end{array}$ & $\begin{array}{c}15.9 \\
(12.0-20.4)\end{array}$ & $\begin{array}{c}0.70 ; 10.55 \\
\underset{\mathrm{d}}{(0.01-190.00)}\end{array}$ & $\begin{array}{l}10 \\
(10)\end{array}$ & $\begin{array}{c}2.3 \\
(1.2-4.1)\end{array}$ & $\begin{array}{c}15.6 \\
(8.2-26.1)\end{array}$ & $\begin{array}{c}0.23 ; 0.68 \\
(0.03-2.03)\end{array}$ & $\begin{array}{l}11 \\
(12)\end{array}$ & $\begin{array}{c}12.2 \\
(6.6-20.3)\end{array}$ & $\begin{array}{c}19.0 \\
(10.8-30.1)\end{array}$ & $\begin{array}{c}0.65 ; 3.02 \\
(0.16-21.40) \\
\mathrm{d}\end{array}$ & $\begin{array}{c}1 \\
(1)\end{array}$ & $\begin{array}{c}20.0 \\
(1.0-66.6)\end{array}$ & $\begin{array}{c}33.3 \\
(1.7-86.8)\end{array}$ & 2.9 \\
\hline Total & $\begin{array}{c}281 \\
(296)\end{array}$ & $\begin{array}{c}0.9 \\
(0.8-1.0)\end{array}$ & 100.0 & $\begin{array}{c}1.64 ; 14.40 \\
\underset{\mathrm{d}}{(0.01-654.50)}\end{array}$ & $\begin{array}{l}63 \\
(64)\end{array}$ & $\begin{array}{c}14.7 \\
(11.6-18.3)\end{array}$ & 100.0 & $\begin{array}{c}0.42 ; 4.05 \\
(0.02-81.96)\end{array}$ & $\begin{array}{l}59 \\
(63)\end{array}$ & $\begin{array}{c}65.6 \\
(55.3-74.8)\end{array}$ & 100.0 & $\begin{array}{c}1.45 ; 4.46 \\
\underset{\mathrm{d}}{(0.02-28.00)}\end{array}$ & $\begin{array}{l}3 \\
(3)\end{array}$ & $\begin{array}{c}60.0 \\
(18.2-92.7)\end{array}$ & 100.0 & $\begin{array}{l}11.28 ; 11.71 \\
(290-20.96)\end{array}$ \\
\hline
\end{tabular}

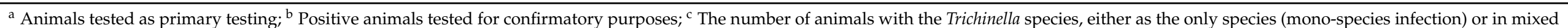

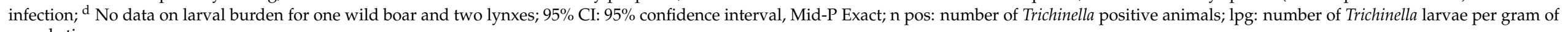
muscle tissue. 
The second most common Trichinella species was T. nativa, was found in all the investigated host species except badgers. Infected animals originated from 11 of the 15 counties; no findings were detected on the islands Hiiumaa and Saaremaa, and the southeastern counties Võrumaa and Valgamaa (Fig. 2, Table S2). Trichinella nativa was found in $0.1 \%$ (95\% CI 0.0-0.1) of wild boars, $5.8 \%$ (95\% CI 3.9-8.4) of brown bears, and $20.0 \%$ (95\% CI 12.7-29.2) of lynxes (Table 2$)$.

Trichinella pseudospiralis was found in 2009 for the first time in wild boars in Estonia (Table $1 ;[11,16]$ ). During the study period, this species was found in $0.02 \%$ of wild boars (Table 2); the prevalence was highest in Saaremaa, 0.2\% (95\% CI 0.1-0.5; Table S2).

The first Trichinella spiralis finding in a game animal in Estonia was identified in a lynx hunted in 2008 (shipped and tested in 2009), and further findings were detected in wild boars and lynxes hunted in 2009. The species was found in $0.03 \%$ (95\% CI 0.0 0.05 ) of wild boars and $4.4 \%$ (95\% CI 1.4-10.4) of lynxes (Table 2). It was detected in nine counties: Harjumaa, Järvamaa, Läänemaa, Lääne-Virumaa, Põlvamaa, Pärnumaa, Raplamaa, Saaremaa, and Viljandimaa (Table S2).

\section{Discussion}

The high number of observations in this study add substantially to the knowledge on epidemiology of Trichinella spp. in Estonia and highlight that wildlife, including game animals, have a key role in it. Trichinella spp. are important zoonotic parasites in the country and the region [17], and it is crucial that the One Health approaches addressing them cover not only domestic animals and humans, but also wildlife.

It should be emphasized that hunted animals are always a convenience sample: hunting periods affect the age of the animals included in the sample, and the representativeness of a hunter-harvested sample is challenging to evaluate. Moreover, it should be noted that e.g., animals injured in traffic accidents or hunted illegally are not included in the official hunting statistics. This could explain the higher number of brown bears in our sample than in the hunting bags.

The sampling was done by hunters and veterinary inspectors, who were advised to sample from the predilection muscle groups, if these were available [10]. The sampling was not supervised by the authors, and possible variation in sample material may have affected the results to the direction of underestimation of the prevalence and in particular of the larval burden. The predilection muscle groups vary by host species [10], and for detailed comparisons, sampling the exact same muscle within each host species would be optimal.

The background information on the animals was provided by the hunters, and the authors had no means to validate these data. Misclassification of some animals to wrong age category or sex remain possible, and no data were provided for many animals (Table 1; Table S1).

The methodology we used is harmonized at international level and thus yields comparable results. The prevalence estimates reported in this study are generally in line with results from previous studies focusing on these host species in Estonia, which estimated the prevalence to be $0.3-1.0 \%$ in wild boars, $29.4 \%$ in brown bears, and $47.4-50 \%$ in lynxes $[8,18]$. The proportion of badgers that tested positive in this study was significantly higher $(60.0 \%$, three of five, $p=0.006)$ than an earlier estimate for badgers hunted in 1965-2000 (6.7\%, six of 89) [19].

While the results of this study are not directly comparable with those from other countries due to different sampling and study designs, it is clear that Trichinella parasites thrive in the region. The prevalence in wild boars in this study was lower than that observed in Latvia [20], but higher than that in Poland [21]. The prevalence in brown bears and lynxes was higher than that in Finland [22], while the prevalence in lynxes was lower than that in Latvia $[8,23]$. The prevalence in badgers is considered low in several countries [24], however the proportion of positives in this study was substantial, in line with what has been observed in Latvia, and higher than that in Finland [22,23]. 
The results of this study confirm that $T$. britovi has been winning host-terrain, while T. nativa is well-established in whole mainland Estonia. It is noteworthy that T. pseudospiralis was found in animals from the southwestern part of the country. Several studies have described an increase of T. pseudospiralis findings in wild boar samples in Europe [25]. One possible vector of T. pseudospiralis are predatory birds, including migratory birds [25]. In Estonia, the findings of T. pseudospiralis have been made in animals killed near the sea or wetlands areas, which are good nesting sites for birds. Further research focusing on the potential host species living in these specific environments could provide insight into the role of birds in the epidemiology of T. pseudospiralis. Another noteworthy finding was T. spiralis from a lynx killed in 2009 in Järvamaa county, approximately $30 \mathrm{~km}$ from where a human trichinellosis outbreak was documented ten years earlier, and where T. spiralis was found in a domestic pig during the investigation [18]. Trichinella spiralis could be infecting wildlife in Estonia similarly as described by Oksanen and others [22], as spillover from the domestic cycle. That we did not find freeze-sensitive T. spiralis in the main reservoir animal host species in our previous study [6] might be explained by two consecutive colder years before 2011/2012 [26].

In contrast to our previous epidemiological study in the reservoir hosts raccoon dogs and red foxes, where no obvious geographical differences in Trichinella prevalence were seen [6], geographical differences in the prevalence were observed in wild boars and lynxes in this study. Interestingly, we previously demonstrated a higher seroprevalence in wild boars in the southwestern part of the country [7], and the results of this study confirm a higher infection prevalence in western and southern counties. The geographical variation may be due to several factors, including climate, temperature, and snow cover [16,20].

The results of this study exemplify that wild boars can serve as an indicator for Trichinella spp. monitoring, being annually hunted in high numbers and routinely tested for Trichinella. Wild boars have been popular game in Estonia after their population rapidly increased since the second half of the 1990s, supported by relatively mild winters and supplementary feeding [27-30]. Importantly, the results of this study reflect the situation before the African swine fever (ASF) outbreak in Estonia, which started in September 2014, and will thus serve as baseline data for future studies that could evaluate how the ASF-related changes affected the wild boar population and the parasites these animals can host.

The results of this study highlight that testing wildlife hunted for human consumption for Trichinella remains important, and that there is room for improvement in the proportion of hunted animals tested. Wildlife are important for epidemiology of Trichinella spp. in Estonia, and hunting wild game for human consumption provides a potential transmission route to humans.

\section{Conclusions}

In Estonia, Trichinella infections are common in wildlife, including in game animals hunted for human consumption. High infection pressure was evident in sylvatic cycles, and the risk for spillover to and from domestic cycles and transmission to humans remain relevant.

Supplementary Materials: The following are available online at https:/ / www.mdpi.com/2076-261 5/11/1/183/s1: Table S1: Primary testing included in the study: number of wild boars (Sus scrofa), brown bears (Ursus arctos), Eurasian lynxes (Lynx lynx) and badgers (Meles meles) tested for Trichinella in Estonia, 2007-2014, by sex, age category, county, and by year. Table S2: Prevalence of Trichinella infection in wild boars (Sus scrofa), brown bears (Ursus arctos), Eurasian lynxes (Lynx lynx) and badgers (Meles meles) hunted in Estonia, 2007-2014, by county. Univariable odds to test positive in comparison to the reference county (Harjumaa), and larval burden data and the Trichinella species identified are summarized.

Author Contributions: Conceptualization, A.K., B.L. and P.J.; methodology, A.K., B.L. and P.J.; investigation, A.K., L.H. and A.V.; data curation, A.K., B.L. and P.J.; writing-original draft preparation, A.K., B.L. and P.J.; writing-review and editing, B.L and P.J.; supervision, B.L. and P.J. All authors 
contributed to the writing process. All authors have read and agreed to the published version of the manuscript.

Funding: This research received no external funding.

Institutional Review Board Statement: Not applicable.

Informed Consent Statement: Not applicable.

Data Availability Statement: Data is contained within the article or supplementary material.

Acknowledgments: We thank the hunters and veterinary inspectors for collecting the samples and providing the background information about the animals. We thank Ingrid Ott and Moonika Musting from Tartu VFL, Ülla Rajamets and Kristel Lilles from Tallinn VFL, Eda Laas and Merle Reiman from Rakvere VFL, Mai Truutsi from Saaremaa VFL for performing laboratory analyses and collecting data, and Katrin Lõhmus for helping with the laboratory database. We thank European Union Reference Laboratory for Parasites for the species identification of Trichinella larvae collected in 2007-2010, and Edoardo Pozio and Gianluca Marucci for the excellent training in the multiplex PCR method.

Conflicts of Interest: The authors declare no conflict of interest.

\section{References}

1. Bouwknegt, M.; Devleesschauwer, B.; Graham, H.; Robertson, L.J.; Van Der Giessen, J.W.; Participants, T.E.-F.W. Prioritisation of food-borne parasites in Europe, 2016. Eurosurveillance 2018, 23, 17-00161. [CrossRef]

2. The European Union summary report on trends and sources of zoonoses, zoonotic agents and food-borne outbreaks in 2017. EFSA J. 2018, 16, e05500. [CrossRef]

3. Health Protection Inspectorate. Communicable Disease Statistics in Estonia. Part 9. Trichinellosis; Jõgiste, A., Varjas, J., Märtin, J., Aro, T., Kutsar, K., Eds.; Health Protection Inspectorate: Tallinn, Estonia, 2000; pp. 88-93. ISBN 9985918673.

4. European Food Safety Authority and European Centre for Disease Prevention and Control. The European Union summary report on trends and sources of zoonoses, zoonotic agents and food-borne outbreaks in 2015. EFSA J. 2016, 14, 135-145. [CrossRef]

5. Lassen, B.; Janson, M.; Viltrop, A.; Neare, K.; Hütt, P.; Golovljova, I.; Tummeleht, L.; Jokelainen, P. Serological Evidence of Exposure to Globally Relevant Zoonotic Parasites in the Estonian Population. PLoS ONE 2016, 11, e0164142:1-e0164142:13. [CrossRef]

6. Kärssin, A.; Häkkinen, L.; Niin, E.; Peik, K.; Vilem, A.; Jokelainen, P.; Lassen, B. Trichinella spp. biomass has increased in raccoon dogs (Nyctereutes procyonoides) and red foxes (Vulpes vulpes) in Estonia. Parasites Vectors 2017, 10, 609:1-609:12. [CrossRef]

7. Kärssin, A.; Velström, K.; Gómez-Morales, M.A.; Saar, T.; Jokelainen, P.; Lassen, B. Cross-Sectional Study of Anti-Trichinella Antibody Prevalence in Domestic Pigs and Hunted Wild Boars in Estonia. Vector Borne Zoonotic Dis. 2016, 16, 604-610. [CrossRef] [PubMed]

8. Malakauskas, A.; Paulauskas, V.; Järvis, T.; Keidans, P.; Eddi, C.; Kapel, C.M. Molecular epidemiology of Trichinella spp. in three Baltic countries: Lithuania, Latvia, and Estonia. Parasitol. Res. 2007, 100, 687-693. [CrossRef] [PubMed]

9. Estonian Environment Agency. Hunting Statistics. 2019. Available online: https://www.keskkonnaagentuur.ee/et/ ulukiseireulevaated (accessed on 29 April 2019).

10. European Commission. Commission Regulation (EC) No 2075/2005 of 5 December 2005 laying down specific rules on official controls for Trichinella in meat. Off. J. Eur. Union 2005, 48, 452-474.

11. International Trichinella Reference Centre. Database of Trichinella isolates. Available online: https://trichinella.iss.it/Trichinella/ Database (accessed on 25 September 2019).

12. Pozio, E.; La Rosa, G. Trichinella . In Molecular Detection of Foodborne Pathogens; Liu, D., Ed.; CRC Press, Taylor \& Francis Group: Boca Raton, FL, USA, 2010; pp. 851-863.

13. Dean, A.G.; Sullivan, K.M.; Soe, M.M. OpenEpi: Open Source Epidemiologic Statistics for Public Health, Version 3.01. 2019. Available online: www.OpenEpi.com (accessed on 8 May 2020).

14. R Core Team. R: A language and environment for statistical computing. R Foundation for Statistical Computing, Vienna, Austria. 2019. Available online: https:/ / www.R-project.org (accessed on 13 November 2019).

15. Veterinary and Food Laboratory. Available online: http://www.vetlab.ee (accessed on 13 November 2019).

16. Pozio, E. Adaptation of Trichinella spp. for survival in cold climates. Food Waterborne Parasitol. 2016, 4, 4-12. [CrossRef]

17. Deksne, G.; Davidson, R.K.; Buchmann, K.; Kärssin, A.; Kirjušina, M.; Gavarāne, I.; Miller, A.L.; Pálsdóttir, G.R.; Robertson, L.J.; Mørk, T.; et al. Parasites in the changing world-Ten timely examples from the Nordic-Baltic region. Parasite Epidemiol. Control 2020, 10, e00150:1-e00150:11. [CrossRef]

18. Järvis, T.; Miller, I.; Pozio, E. Epidemiological studies on animal and human trichinellosis in Estonia. Parasite 2001, 8, 86-87. [CrossRef] [PubMed]

19. Miller, I. Trichinellosis in Estonia: Epidemiology, Diagnosis and Control. Ph.D. Thesis, Estonian University of Life Sciences, Tartu, Estonia, 2003. 
20. Kirjušina, M.; Deksne, G.; Marucci, G.; Bakasejevs, E.; Jahundoviča, I.; Daukšte, A.; Zdankovska, A.; Běrzina, Z.; Esite, Z.; Bella, A.; et al. A 38-year study on Trichinella spp. in wild boar (Sus scrofa) of Latvia shows a stable incidence with an increased parasite biomass in the last decade. Parasites Vectors 2015, 8, 137-138. [CrossRef]

21. Flis, M.; Grela, E.R.; Gugała, D. Epizootic and epidemiological situation of Trichinella sp. infection in Poland in 2006-2015 in view of wild boar population dynamics. J. Vet. Res. 2017, 61, 181-187. [CrossRef] [PubMed]

22. Oksanen, A.; Interisano, M.; Isomursu, M.; Heikkinen, P.; Tonanzi, D.; Oivanen, L.; Pozio, E. Trichinella spiralis prevalence among wildlife of a boreal region rapidly reduced in the absence of spillover from the domestic cycle. Vet. Parasitol. 2018, 262, 1-5. [CrossRef]

23. Deksne, G.; Seglina, Z.; Jahundoviča, I.; Esīte, Z.; Bakasejevs, E.; Bagrade, G.; Keidāne, D.; Interisano, M.; Marucci, G.; Tonanzi, D.; et al. High prevalence of Trichinella spp. in sylvatic carnivore mammals of Latvia. Vet. Parasitol. 2016, 231, 118-123. [CrossRef]

24. Moskwa, B.; Goździk, K.; Bień, J.; Bogdaszewski, M.; Cabaj, W. Molecular identification of Trichinella britovi in martens (Martes martes) and badgers (Meles meles); new host records in Poland. Acta Parasitol. 2012, 57, 402-405. [CrossRef]

25. Pozio, E. Trichinella pseudospiralis an elusive nematode. Vet. Parasitol. 2016, 231, 97-101. [CrossRef]

26. Rjazin, J.; Pärn, O.; Alari, V. CLASSIFYING THE ICE SEASONS 1982-2016 USING THE WEIGHTED ICE DAYS NUMBER AS A NEW WINTER SEVERITY CHARACTERISTIC. EUREKA: Phys. Eng. 2017, 5, 49-56. [CrossRef]

27. Veeroja, R.; Männil, P. Population Development and Reproduction of Wild Boar (Sus scrofa) in Estonia. Wildl. Biol. Pract. 2013, 10, 17-21. [CrossRef]

28. Oja, R.; Kaasik, A.; Valdmann, H. Winter severity or supplementary feeding-which matters more for wild boar? Acta Thériol. 2014, 59, 553-559. [CrossRef]

29. Oja, R.; Velström, K.; Moks, E.; Jokelainen, P.; Lassen, B. How does supplementary feeding affect endoparasite infection in wild boar? Parasitol. Res. 2017, 116, 2131-2137. [CrossRef] [PubMed]

30. Statistics Estonia. Hunting Statistics. Available online: http:/ / andmebaas.stat.ee/Index.aspx (accessed on 26 October 2020). 